\title{
Identify the Critical Success Factors of Business Management in Taiwanese Veterans Home
}

\author{
Hung-Ju Chien \\ Minghsin University of Science and Technology, 1 Hsin-Sing Road, Hsin-Fong, Hsinchu County, Taiwan \\ *Corresponding Author: lukechien@must.edu.tw
}

Copyright $@ 2014$ Horizon Research Publishing All rights reserved.

\begin{abstract}
According to a survey conducted by the Council for Economic Planning and Development of Taiwan, the population of adults aged 65 years or above will increase from $11.2 \%$ in 2012 to $20 \%$ in 2025 . The Veterans Affairs Commission (VAC) Taiwan also revealed that until April of 2011, there are 456,866 veterans living in Taiwan (one in fifty Taiwanese residents is a veteran). Their average age is 68.1 years old and the majority of veterans $(56 \%)$ are aged 65 and older. The increase in life expectancy and ongoing growth of aging population has led to new models of aging that empower older people to fulfill their quality of later life. In order to take care of the veterans who have contributed to the country and spent half of their life defending the country, the Veterans Affairs Commission Taiwan is assigned with responsibilities to assist in medical care, home care and other general services. These services were designed to facilitate the transition of military personnel from the armed forces to civilian life. The aim of this paper is to identify the critical successful factors of business management in Taiwanese Veterans Home by Analytic Hierarchy Process (AHP). The author's survey results revealed that the top three critical successful factors of business management in Taiwanese Veterans Home are; service quality of the professional team, long-term care planning and accidents audit plan.
\end{abstract}

Keywords Analytic Hierarchy Process, Critical Successful Factor, Taiwanese Veterans Home

\section{Introduction}

With decreasing birth rates and increasing life expectancy, Taiwan is facing the economic impact of the aging population on its health care system, especially public funded health care services. Furthermore, with rising expectations for the quality of care, has made health care reform a major task of the Taiwanese government (Leung et al., 2004). It is estimated that the Taiwanese population aged 65 and older will grow to $14 \%$ of the total population in 2016 and $20 \%$ of the total population in 2025 . Even though aging is not synonymous with frailty, elderly people are major consumers of health care. In the United States, health care spending is expected to grow by two thirds by 2008, and the elderly account for one third of the country's $\$ 112$ billion prescription drug costs, which are growing by more than $10 \%$ a year (Critical Conditions, 2000).

In addition, there are 980,300 Hong Kong people who are 65 years old and above in 2012 (13.7\% of total Hong Kong population). Total expenditure on health amount $\mathrm{HK}$ $\$ 88,721$ million, as $5.2 \%$ of Gross Domestic Product (GDP). Wong (2013) reported that Hong Kong will have to spend much more than expected on elderly health care in future, according to revised government predictions that show previous estimates were far too low. Furthermore, by 2030 , almost one in three people will be 65 or older in Japan. Meeting the needs of an ageing population, the Japanese government provides universal health care coverage for its population while spending around $8.5 \%$ of GDP (Curry, 2012).

According to the Veterans Affairs Commission (VAC), Taiwan survey in April of 2011, there are 456,866 veterans living in Taiwan (one in fifty Taiwanese residents is a veteran, see Table 1). Their average age is 68.1 years old and the majority of veterans $(56 \%)$ are aged 65 and older (VAC, 2011). There are two salient demographic changes that will take place in the Taiwanese veteran population over the next ten years, which will greatly affect the demand for long-term care and other services (Washington State Department of Veterans Affairs, 2006). These demographic changes include:

- An extraordinary increase in the veteran population aged 80 and older;

- The highest proportion of aging veterans is male. 
Table 1. Number of Taiwanese Veterans - by Age

\begin{tabular}{|c|c|c|c|c|}
\hline Categories & $20-49$ years old & $50-64$ years old & 65 years old \& over & Total \\
\hline 2007 & 105,064 & 91,205 & 295,265 & 491,534 \\
\hline 2008 & 103,215 & 95,662 & 283,225 & 482,102 \\
\hline 2009 & 98,143 & 101,668 & 271,495 & 471,306 \\
\hline 2010 & 92,574 & 109,457 & 259,604 & 461,635 \\
\hline Until April 2011 & 90,608 & 111,424 & 254,834 & 456,866 \\
\hline
\end{tabular}

Source: Veterans Affairs Commission (2011)

Over the next 10 years, the number of veterans aged 65 and older in Taiwan will remain relatively stable, fluctuating between 200,000 and 250,000. However, there will be a sharp rise in veterans aged 80 and older. According to VAC, Taiwan (2011) projections, the number of veterans age 80 and over will increase by $20 \%$ between 2011 and 2021 . The growth in very elderly veterans is resulting in increased demands for long-term care, including special needs such as hospice care and care for Alzheimer's and other dementia conditions. According to the Washington State Department of Veterans Affairs (WDVA, 2006) study on prevalence rates for Alzheimer's, it is estimated that approximately 16,000 Washington veterans aged 65 and older will be diagnosed with this disorder by 2010, representing an increase of almost $100 \%$.

One unique characteristic of older Taiwanese veterans that affect service needs is the high proportion of males $-97 \%$ of veterans over the age of 65 are males, compared to $50 \%$ for the country population as a whole - and the presence of wartime disabilities, both physical and mental. Using data from a VAC, Taiwan (2011) statistic, approximately 10,000 veterans aged 65 and over in Taiwan are currently receiving war-related disability compensation or pensions from the central government.

The main purpose of a veterans home is to achieve their organisational mission and vision which include insuring the vitality of the armed forces, securing social stability and prosperity, maximising human resources and supporting national reconstruction. In addition, they need to focus on customer satisfaction in order to maintain sustainable service operations (Predrag, 2011). This paper addresses the emerging phenomenon of providing a health care system for an aging population. It also identifies the critical success factors of business management in the Taiwanese Veterans Home (TVH).

\section{Introduction to Taiwanese Veterans Homes}

In order to take care of the veterans who have contributed to the country and spent half of their life defending the country, the Taiwan VAC is assigned with responsibilities to assist in educational support, employment assistance, medical care, home care and other general services. These services were designed to facilitate the transition of military personnel from the armed forces to civilian life. It is also concerned with improving their quality of later life (Veterans Affairs Commission, 2011). According to the Republic of China (ROC) Veterans Assistance Act, the VAC is to set up institutes to provide home-care for veterans. Under these principles, the VAC has set up 14 veteran's homes and 4 domiciliary centres to provide home-care services in following categories.

\subsection{Home-care at Government's Expenses}

Veterans aged 61 and older, receiving less than an average monthly income of NT $\$ 13,550$ (about USD 417) and holding a valid household registration in Taiwan as well as those service connected injured or sick veterans, are entitled to VAC home-care of this category. In addition, qualified single veterans are encouraged to live inside the veterans homes. To the end of April 2011, Taiwanese veterans homes provide 6,862 beds at the government's expense (see Table 2). Currently, 6,577 veterans are living in veterans homes, with bed occupancy rates of $96 \%$ (Veterans Affairs Commission, 2011).

\subsection{Home-care at Self-expenses Domiciliary}

Veterans aged 61 and older, and who are financially capable to support their own home-care services are included in this category. If the applicants are married, their spouses, over 50 years old, are qualified to apply with the veterans as well, but they should be able to handle their daily activities. To the end of April 2011, Taiwanese veteran's homes and domiciliary centres provide 2,769 beds at a self-expense domiciliary (see Table 3). Currently, 2,107 veterans are living in veterans homes and domiciliary centres, where the occupancy rate of beds is $76 \%$ (Veterans Affairs Commission, 2011). 
Table 2. Number of Beds of Veterans Homes at Government's Expense

\begin{tabular}{|c|c|c|c|c|}
\hline Categories & $\begin{array}{c}\begin{array}{l}\text { Independent } \\
\text { domiciliary }\end{array} \\
\end{array}$ & $\begin{array}{c}\text { Nursing care / } \\
\text { disabled }\end{array}$ & $\begin{array}{c}\text { Nursing care / } \\
\text { Dementia }\end{array}$ & Total \\
\hline Banciao Veterans Home & 150 & & & 150 \\
\hline Taipei Veterans Home & 639 & 270 & 70 & 979 \\
\hline Taoyuan Veterans Home & 416 & 158 & 50 & 624 \\
\hline Hsinchu Veterans Home & 348 & 176 & & 524 \\
\hline Changhua Veterans Home & 327 & 144 & 80 & 551 \\
\hline Yunlin Veterans Home & 178 & 200 & & 378 \\
\hline Baihe Veterans Home & 263 & 169 & & 432 \\
\hline Jiali Veterans Home & 278 & 68 & & 346 \\
\hline Tainan Veterans Home & 348 & 93 & & 441 \\
\hline Gangshan Veterans Home & 548 & 211 & 100 & 859 \\
\hline Pingtung Veterans Home & 142 & 174 & 60 & 376 \\
\hline Hualien Veterans Home & 330 & 130 & & 460 \\
\hline Taiping Veterans Home & 188 & 94 & 67 & 349 \\
\hline Malan Veterans Home & 252 & 141 & & 393 \\
\hline Total & 4,407 & 2,028 & 427 & 6,862 \\
\hline
\end{tabular}

Source: Veterans Affairs Commission (2011)

Table 3. Number of Beds of Veterans Homes at Self-expense Domiciliary

\begin{tabular}{|c|c|c|c|c|}
\hline Categories & $\begin{array}{c}\text { Independent } \\
\text { domiciliary }\end{array}$ & $\begin{array}{c}\text { Nursing care / } \\
\text { disabled }\end{array}$ & $\begin{array}{c}\text { Nursing care / } \\
\text { Dementia }\end{array}$ & Total \\
\hline Taipei Veterans Home & & 45 & 20 & 65 \\
\hline Taoyuan Veterans Home & & 69 & 27 & 96 \\
\hline Hsinchu Veterans Home & 26 & 24 & & 50 \\
\hline Changhua Veterans Home & & & 20 & 20 \\
\hline Yunlin Veterans Home & & 200 & & 200 \\
\hline Baihe Veterans Home & 87 & 70 & & 157 \\
\hline Jiali Veterans Home & 26 & & & 26 \\
\hline Tainan Veterans Home & 61 & 30 & & 91 \\
\hline Gangshan Veterans Home & 2 & & & 2 \\
\hline Pingtung Veterans Home & & 100 & 40 & 140 \\
\hline Hualien Veterans Home & 10 & 20 & & 30 \\
\hline Taiping Veterans Home & 6 & 62 & 25 & 93 \\
\hline Malan Veterans Home & 15 & 19 & & 34 \\
\hline Bade Domiciliary Center & 666 & 34 & & 700 \\
\hline Changhua Domiciliary Center & 352 & 32 & & 384 \\
\hline Nanzih Domiciliary Center & 408 & 75 & & 483 \\
\hline Hualien Domiciliary Center & 183 & 15 & & 198 \\
\hline Total & 1,842 & 795 & 132 & 2,769 \\
\hline
\end{tabular}




\subsection{Home-care Resource Sharing}

In order to build up better neighbourhood relationships and facilitate better use of government resources the VAC has launched a new project to share its home-care facilities with civilians in the vicinity from 2007. VAC veterans homes and domiciliary centres are instructed to offer day-care centres and the rehabilitation facilities inside the home-care institutes to the nearby civilians (Veterans Affairs Commission, 2011).

Currently, there are a lot of challenges facing Taiwanese veterans homes on future developments, for example, accommodating a continued decrease in the number of veterans. There were 598,000 veterans in 1991, but in April 2011 there are only 456,866 veterans living in Taiwan, decreasing by more than 7,000 veterans a year. Holmes (1996) indicated that a proxy measure of financial performance is the occupancy rate of the facility. Facilities with high occupancy rates are likely to be more profitable or at least have greater economies of scale. This should enable veterans homes to increase service provisions. As a consequence, these facilities may also be more likely to have improved resident outcomes (Castle and Banaszak-Holl, 2003).

Although Taiwanese veterans homes are public funded health care services, Kaplan and Norton (2001) stated that both profit and non-profit organisations need to focus on profitability and customer satisfaction in order to maintain sustainable business operations. Therefore, it is important to increase the occupancy rate of the facility for Taiwanese veterans homes on future developments.

\section{Critical Success Factors of Non-Profit Organization, Nursing Home and Veterans Home}

The Critical Success Factors (CSFs) are interdependent; one is not more important than another. However, the success factors cascade down and build on one another beginning with a shared mission, values, vision and direction and then proceeding to clearer definitions of relationships and processes (Mollenhauer, 2006, see Figure 1).

The idea of CSFs was first presented by Ronald Daniel in the 1960s. It was then built on and popularized a decade later by John F. Rockart, of MIT Sloan School of Management and he has since been used extensively to help businesses implement their strategies and projects (MindTools, 2013). Rockart also defined CSFs as: 'The limited number of areas in which results, if they are satisfactory, will ensure successful competitive performance for the organisation. They are the few key areas where things must go right for the business to flourish. If results in these areas are not adequate, the organisation's efforts for the period will be less than desired.' He also concluded that CSFs are 'areas of activity that should receive constant and careful attention from management' (MindTools, 2013). Critical Success Factors are therefore strongly related to the mission and strategic objectives of business or project. Whereas the mission and objectives focus on the aims and what is to be achieved, Critical Success Factors focus on the most important areas and get to the very heart of both what is to be achieved and how business will achieve it.

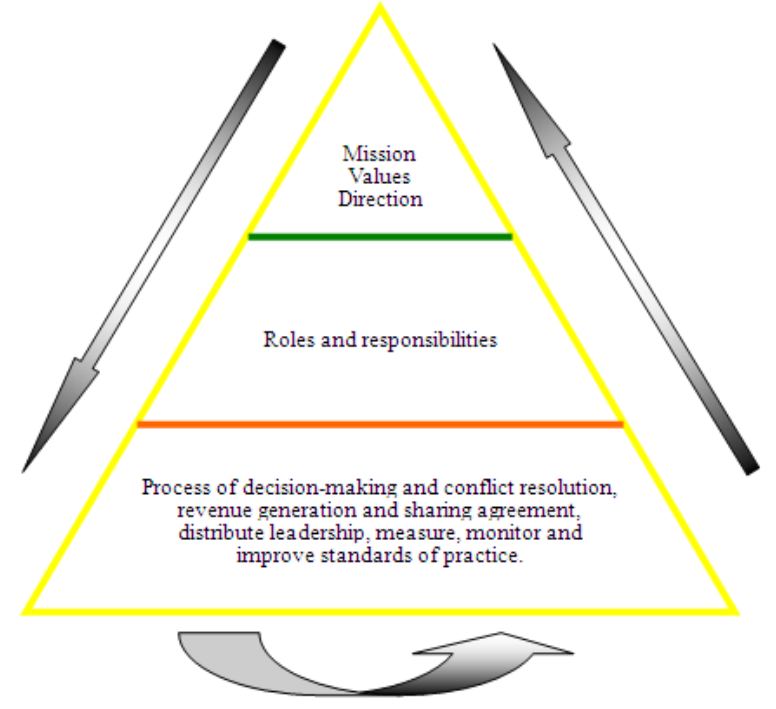

Source: Mollenhauer (2006) adapted by author

Figure 1. Triangle of success factors

Veterans home staff must articulate clear and meaningful values that drive their behaviour. For example, Veterans home values might be to; ensure that the veterans served come first, value the different capacities and interests of all veterans, consistently aim for efficiency and effectiveness and communicate in an open and transparent fashion (Mollenhauer, 2006). In addition, the division of roles and responsibilities reflect the veterans homes values and are based on what each part of the veterans home can do most effectively. There is a clear value added and no duplication of effort. Additionally, the roles and responsibilities are based on realistic expectations because they take into consideration the various capacities of homes. Once the role and responsibilities are established, a successful veterans home ensures that each member of staff is fulfilling their role (Mollenhauer, 2006).

\subsection{Critical Success Factors of a Non-Profit Organization}

Kaplan and Norton (2001) proposed a non-profit organisation structure to establish the four major Balanced Score Card (BSC) perspectives. The organisational mission is at the top followed by the customer, internal process, learning and growth, and financial perspectives. Through the balanced score card approach, each individual will find his or her orientation and connection within the organisation and will determine how to satisfy customer requirements, improve organisational financial performance and contribute to staff growth (Lawrence and Sharma, 2002; Wilson et al., 2003; Kaplan and Norton, 2004; Chen et al., 2006). 
Table 4. Measures for improved and modified BSC objectives of the non profit organisation

\begin{tabular}{|c|c|c|c|}
\hline Objectives & \multicolumn{3}{|c|}{ Measures } \\
\hline $\begin{array}{c}\text { Develop needed workforce skills and } \\
\text { competencies }\end{array}$ & $\begin{array}{c}\text { Retain best qualified } \\
\text { staff }\end{array}$ & $\begin{array}{c}\text { Track all external trainings } \\
\text { and conferences for } \\
\text { division and departments }\end{array}$ & $\begin{array}{c}\text { Communications and } \\
\text { marketing plan is developed } \\
\text { and executed }\end{array}$ \\
\hline $\begin{array}{c}\text { Ensured organisational learning based } \\
\text { on data, outcomes and experience }\end{array}$ & Turnover rate & Organisational learning & Promotion rate \\
\hline $\begin{array}{c}\text { Deliver services aligned with } \\
\text { resources and prioritised core } \\
\text { activities }\end{array}$ & Number of consults & Process efficiency & Marketing performance \\
\hline $\begin{array}{c}\text { Build professional competencies that } \\
\text { support strategy }\end{array}$ & $\begin{array}{c}\text { Number of solutions } \\
\text { evaluated }\end{array}$ & $\begin{array}{c}\text { Number of joint projects in } \\
\text { new or emerging markets }\end{array}$ & $\begin{array}{c}\text { Level of satisfaction with } \\
\text { newly implemented solutions }\end{array}$ \\
\hline $\begin{array}{c}\text { Understand customer segments } \\
\text { customers }\end{array}$ & $\begin{array}{c}\text { Number of repeat } \\
\text { high-quality services }\end{array}$ & $\begin{array}{c}\text { Number of services available } \\
\text { to customers }\end{array}$ \\
\hline $\begin{array}{c}\text { Provide quality programs that are } \\
\text { superbly executed }\end{array}$ & $\begin{array}{c}\text { Number of hours spent } \\
\text { with customer }\end{array}$ & Market share & Customer loyalty program \\
\hline Average gift amount & Number of safety incidents from new products & $\begin{array}{c}\text { Revenue from markets and } \\
\text { segments }\end{array}$ \\
\hline Achieve financial sustainability & $\begin{array}{c}\text { Revenue growth vs } \\
\text { budget targets }\end{array}$ & Number of new business opportunity identifications \\
\hline $\begin{array}{c}\text { Be the best managed non-profit } \\
\text { organisation in the country }\end{array}$ & \multicolumn{2}{|c|}{ Marketing, selling, distribution and administrative as percent of total cost } \\
\hline
\end{tabular}

Source: Predrag (2011)

Table 4 demonstrates BSC measures for improvement and modified objectives of the non-profit organisation. Non-profit organisations must emphasise the financial costs and benefits of business management. Without awareness of the complete financial structure, including resources and budgets, it is impossible to achieve a vision or mission (Predrag, 2011). Many non-profit organisations have admirable mission and vision statements but lack adequate financial support, which results in poor performance. Fletcher and Smith (2004) suggested that the learning and growth perspective was the leading indicator of the internal business process, which in turn, was the leading indicator of customer satisfaction. A degree of improvement in internal business processes and the level of customer satisfaction will also affect the financial perspective.

In addition, Predrag (2011) stated that non-profit organisational members that have core abilities in quality awareness can improve their internal processes to increase administrative efficiency. He further indicated that if the organisational services and education are of good quality and adequate operational facilities, customer requirements will be satisfied. When non-profit organisational internal and external customers are satisfied with its performance, its profit growth will most likely be positive and sustainable. Therefore, an adequate financial structure helps a non-profit organisation achieve their mission and vision.

A survey of Employee Volunteering Program (EVP) for the small to medium Not-for Profit Sector (NFPs) conducted by Dalton et al. (2008) revealed that interviewees generally said that the commitment of volunteers was important. Their reliability contributed to the success of the EVP. Moreover, quantitative data revealed that a key point to success is the relationship between NFPs and corporations. Good communication, clarity of purpose and direction, understanding each other and good management were also significant themes. Mutual benefit was achieved via skills and experience exchange. Some stated good planning of a project is also a crucial factor.

\subsection{Critical Success Factors Of Nursing Home}

Nursing homes are being challenged in many ways. For example, there is an ever-growing elderly cohort, patients may be admitted to nursing homes in poor health conditions and reimbursement for nursing homes services may not be adequate (Childs, 2000). These trends are likely to continue. Nursing Homes therefore may need better leadership qualities within the industry so that they can improve services to the elderly. Castle and Banaszak-Holl (2003) believed that it is equally obvious that the administration of nursing homes may determine the context and content of nursing home care and may also have an important effect on quality.

The Institute of Medicine (IOM) estimated that more than half of the nursing homes in the United States of America (USA) provided low standards of care (IOM, 1986). Several USA government reports also indicated that many of their nursing homes have serious quality problems that can harm residents (General Accounting Office, 1999a, 1999b, 1999c). Harrington et al. (2000) found that administrative staff time was not related to any deficiencies for resident care but was inversely related to non-health deficiencies. Castle and Banaszak-Holl (2003) agreed and stated that the ability of administration to react to resident outcomes and code violations on state inspections may be tied to the organisation's financial performance. They also indicated that competition may be an important influence on the behaviour of administration, especially in promoting quality care.

In addition, a research carried out by Castle and 
Banaszak-Holl (2003) revealed that the effective staffing levels of nurses need to be larger than those for administration. They believed that administrative staffing is important but clearly not as influential as caregiver staffing. Previous research has identified high rates of administrator turnover in nursing homes (Singh \& Schwab, 1998). Rubin and Shuttlesworth (1986) surveyed the average turnover of administrators to be $33 \%$ per year. Furthermore, A recent study using data from five states of the USA found turnover rates to average $43 \%$ per year (Castle, 2001). Additionally, several studies have identified turnover of administrators in nursing homes as a potential influence on quality of care, therefore making an understanding of the factors associated with turnover even more pressing (Christensen \& Beaver, 1996; Singh et al., 1996).

Castle and Shugarman (2005) also indicated that administrator turnover is affected by both organisational characteristics and the personal characteristics of top managers. They also showed that top management teams with longer tenured administrators are $40 \%$ less likely to leave the organisation than those with shorter tenure. Therefore, increased tenure is generally associated with stability within a facility. Currently, care facilities are facing increasing pressure to provide higher staffing levels. Several states of the USA, for example, have mandated minimum staffing levels (Mueller et al., 2006). This clearly comes at an added expense for the facility. Castle (2008) indicated that one beneficial outcome of higher staffing levels could be lower staff turnover.

Following nursing home admission, family members of the new resident and the health care staff should interact with each other. Some staff mistakenly think that family members abandon their relatives once they are admitted to the nursing home (Rowles \& High, 2003), but the reality is that most family and friends remain involved in the care of their relative through visits and phone calls (Port et al., 2001). A recent research has shown that family members value effective relationships with nursing home staffs that they see as a source of information and a means of remaining involved in care decisions. Family members who also possess information about residents' preferences, habits and goals of care can assist staff to establish an optimal plan of care that contributes to resident well-being (Rowles \& High, 2003).

Wilder (2005) suggested that improved interaction and communication between staff and family are necessary to improve relationships and decrease family complaints that can lead to costly investigations. However, a survey conducted by Utley-Smith et al. (2010) revealed that staff at two nursing homes described staff-family relationships as difficult, problematic and time consuming. An earlier study also revealed that the same was true for families, which contributed to unresolved staff-family member conflicts (Marzialli et al., 2006). Utley-Smith et al. (2010) further identified that differences between the staff attitudes and perceptions of family expectations at two nursing homes could be due to general differences in socioeconomic status.
Working class families are possibly less demanding or more appreciative of the care received by their relative, while the middle and upper middle class families may expect and demand more.

One nursing home introduced a system of communication with family members in the first 72 hours after admission. The program was intended as a preventative strategy to ensure that family members were intended as a preventative strategy to ensure that they were comfortable with their relative's care. During the first 24 hours the admission director telephoned the family, at 48 hours the nurse telephoned the family and at 72 hours the social worker contacted the family. The assistant nursing home administrator admitted that the system was not always followed but believed it worked when it was adhered to.

\section{Materials and Methods}

The Analytic Hierarchy Process (AHP) is a mathematically based, multi-objective decision making tool which was introduced by Saaty (1990). It uses the pair wise comparison method to rank order alternatives of a problem that are formulated and solved in hierarchical structure (Udo, 2000; Coyle, 2004; Saaty, 2008). The AHP approach has been adopted in many applications including project management (Kamal \& Al-Subhi, 2001), project risk management (Dey, 2002) and supplier evaluation and selection (Tahriri, et al., 2008). Additional application areas include problems in vendor selection, information technology outsourcing decision and decision making etc. (Udo, 2000; Saaty, 2008; Kumar, et al., 2009).

Kendrick and Saaty (2007) also indicated that AHP can assist strategy focused organisations in properly managing business process improvement programs. Furthermore, Hepler and Mazur (2007) indicated that the most important outcome of service quality is a design and implementation activity list to assure customer satisfaction. Since most organisations cannot complete this list due to human resource, budget, and time constraints, some prioritisation of the action items is necessary. This prioritising action items is critical to aiming the organisation towards a shared vision. One widely accepted approach to planning, priority setting, and resource allocation in complex situations involving multiple criteria is the AHP. The objective of this survey is to use the AHP method for Critical Success Factor's judgement. In order to comply with collecting quantitative and qualitative data for AHP CSFs model that could be applied in the Taiwanese Veterans Home; a three step approach was performed to ensure successful implementation as follows:

\subsection{Step 1: Structure the Hierarchical Model}

The first step in AHP rating procedure is to establish the criteria and sub-criteria to be used for CSFs judgement. To comply with the criteria for CSFs judgement and their importance required data to be collected based on the 
literature review. Figure 2 shows that three important criteria in the second level and fifteen sub-criteria from the third level were selected to analyse the CSFs for business management of the TVH.

\subsection{Step 2: Prioritise the Order of Criteria and Sub-Criteria}

The mathematics of the AHP and the calculation techniques require a matrix to be constructed that expresses the relative values of a set of attributes. Each of these attributes is assigned a number on a scale (see Table 5). Udo (2000) stated that priority values can also be used as evaluation or performance measures. Businesses, government and even other organisations that seek to perform are able to evaluate their actions with measures of performance. He further explained that Expert Choice is a multi-attribute decision support software tool based on the AHP methodology. This tool can help the decision makers to examine and resolve problems involving multiple evaluation criteria.

To identify the CSFs of business management in the Taiwanese Veterans Home, a questionnaire was conducted, which was designed and based upon the current literature review and research objectives. Before the main survey was undertaken, a draft version of the questionnaire was piloted with one VAC officer, one Veterans Home administrator and also with one eminent academic professor. This pilot study was undertaken to elicit responses that would help to test the wording of the questionnaire, identify ambiguous questions, and also provide an indication of the time to complete the questionnaire. A number of the comments and suggested amendments from the pilot study respondents were used to amend the questionnaire prior to its final distribution.

A total of 81 experts were asked to evaluate the priority of CSFs based on three criteria in the second level and fifteen sub-criteria in the third level by comparing the criteria with each other with respect to the goal. The name and post address of the experts were obtained from the author's network of contacts and also from organisations such as the Veterans Affairs Commission Taiwan, Association of National Universities of Taiwan, Information Service Association of Chinese Colleges, Association of Private Universities and Colleges, and Taiwan Veterans General Hospital. Prior to sending the posted questionnaire, an initial email was sent to each organisation in order to identify the person in the organisation with responsibility for veterans home administration or professional of veterans care.

A total of 52 valid returns were received during January 2013 and March 2013, representing a response rate of $64 \%$. Naoum (1998) however suggests that $40 \%-60 \%$ is a more typical response rate for postal questionnaires. Therefore, the $64 \%$ response rate was considered very acceptable. The data obtained from the questionnaire survey was analysed according to the categories of expert, which was distinguished in three categories as indicated in Table 6.

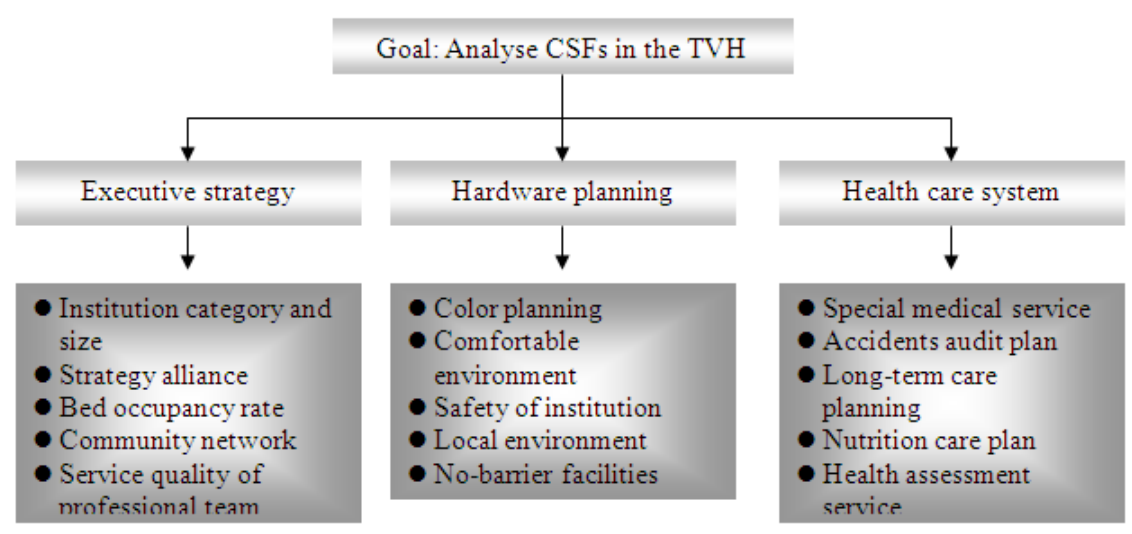

Figure 2. Hierarchy model of CSFs judgement

Table 5. The Saaty rating scale

\begin{tabular}{|c|c|c|}
\hline $\begin{array}{c}\text { Intensity of } \\
\text { importance }\end{array}$ & Definition & Explanation \\
\hline 1 & Equal importance & Two factors contribute equally to the objective \\
\hline 3 & Some what more important & Experience and judgement slightly favour one over the other. \\
\hline 5 & Much more important & Experience and judgement strongly favour one over the other. \\
\hline 7 & Very much more important & $\begin{array}{c}\text { Experience and judgement very strongly favour one over the other. Its } \\
\text { importance is demonstrated in practice. }\end{array}$ \\
\hline 9 & Absolutely more important & $\begin{array}{c}\text { The evidence favouring one over the other is of the highest possible } \\
\text { validity. }\end{array}$ \\
\hline $2,4,6,8$ & Intermediate values & When compromise is needed \\
\hline
\end{tabular}


Table 6. Questionnaire response rate

\begin{tabular}{|c|c|c|c|}
\hline Categories & No. sent & No. returned & Response rate \\
\hline VAC officer & 10 & 5 & $50 \%$ \\
\hline Veterans Home administrator & 59 & 41 & $70 \%$ \\
\hline Academic professor & 12 & 6 & $50 \%$ \\
\hline Average & $\mathbf{8 1}$ & $\mathbf{5 2}$ & $\mathbf{6 4 \%}$ \\
\hline
\end{tabular}

\subsection{Step 3: Calculate the Consistency Ratio and Identify the CSFs}

The final step is to calculate a Consistency Ratio (CR) to measure how consistent the judgements have been relative to large samples of purely random judgements. If the CR is much in excess of 0.1 the judgements are untrustworthy because they are too close for comfort to randomness and the exercise is valueless or must be repeated (Coyle, 2004; Farzad Tahriri et al., 2008). Based on the global priority, weights of each alternative can be evaluated and summarised. The summaries of overall criteria are discussed in next section.

\section{Results}

The results have been classified under the following headings:

a) The results of pair-wise comparison in the second level

b) The results of pair-wise comparison in the third level

c) The overall results of the hierarchy model

\subsection{The results of pair-wise Comparison in the Second Level}

The author's survey results revealed that 'executive strategy' has a weight of 0.332 , 'hardware planning' 0.248 and 'health care system' 0.454 (see Table 7). The interpretation of this survey result is that 'health care system' is the most attractive option of CSFs of business management in the Taiwanese Veterans Home. The result found in the author's survey was also confirmed by a study conducted by Abbott, et al. (2007) who indicated that almost half of the frail male veterans in their study are at risk of having no one to provide instrumental aid and health monitoring support if something should happen to the one person who provides this type of assistance.

The author's survey results also revealed that Consistency Rate (CR) for the integrated matrix of pair-wise comparison of the category VAC officer was 0.01 , VH administrator was 0.00 and academic professor was 0.00 , as these rates are less than 0.1 , it shows the consistency of the comparisons. Therefore, the prioritisations can be considered reliable.

\subsection{The results of Pair-Wise Comparison in the Third Level}

\subsubsection{Within the Executive Strategy Category}

A research survey carried out by Utley-Smith et al. (2010) concluded that by increasing connections and exchange of information between nursing home staff and family members, potentially better outcomes may be realised for nursing home staff members, family members and ultimately residents. Soderstrom et al. (2003) agreed and stated that nurses who promoted inviting interactions with family members by listening, being present and answering questions spent less time with families overall than their non-inviting colleagues. Nurses who used "non-inviting interactions" became defensive and withdrew from family interactions. This led family members to mistrust staff and spend more time on the unit with their relative.

The author's survey results revealed that 'service quality of the professional team' $(0.530)$ is the major critical successful factor within the executive strategy category, followed by 'institution category and size' (0.173) and 'strategy alliance' (0.115) (see Table 8). These findings concur with the study conducted by Castle and Banaszak-Holl (2003) who indicated that the administration of nursing homes may have an important relationship with quality of care.

Table 7. The results of pair-wise comparison in the second level

\begin{tabular}{|c|c|c|c|c|}
\hline Criteria in the second level & VAC officer & VH administrator & Academic professor & The overall \\
\hline Executive strategy & 0.338 & 0.230 & 0.327 & 0.332 \\
\hline Hardware planning & 0.155 & 0.288 & 0.301 & 0.248 \\
\hline Health care system & 0.507 & 0.482 & 0.373 & 0.454 \\
\hline
\end{tabular}


Table 8. The results of pair-wise comparison within executive strategy category

\begin{tabular}{|c|c|c|c|c|}
\hline Executive strategy & VAC officer & VH administrator & $\begin{array}{c}\text { Academic } \\
\text { professor }\end{array}$ & The overall \\
\hline Service quality of professional team & 0.565 & 0.459 & 0.566 & 0.530 \\
\hline Institution category and size & 0.160 & 0.180 & 0.180 & 0.173 \\
\hline Strategy alliance & 0.104 & 0.103 & 0.098 & 0.115 \\
\hline Community network & 0.086 & 0.115 & 0.092 & 0.097 \\
\hline Bed occupancy rate & 0.085 & 0.143 & 0.065 & 0.084 \\
\hline
\end{tabular}

Table 9. The results of pair-wise comparison within hardware planning category

\begin{tabular}{|c|c|c|c|c|}
\hline Hardware planning & VAC officer & VH administrator & $\begin{array}{c}\text { Academic } \\
\text { professor }\end{array}$ & The overall \\
\hline Safety of institution & 0.384 & 0.377 & 0.370 & 0.377 \\
\hline No-barrier facilities & 0.378 & 0.341 & 0.398 & 0.372 \\
\hline Local environment & 0.113 & 0.108 & 0.106 & 0.109 \\
\hline Colour planning & 0.065 & 0.073 & 0.060 & 0.066 \\
\hline Comfortable environment & 0.061 & 0.102 & 0.066 & 0.076 \\
\hline
\end{tabular}

Table 10. The results of pair-wise comparison within health care system category

\begin{tabular}{|c|c|c|c|c|}
\hline Health care system & VAC officer & VH administrator & $\begin{array}{c}\text { Academic } \\
\text { professor }\end{array}$ & The overall \\
\hline Long-term care planning & 0.310 & 0.282 & 0.305 & 0.299 \\
\hline Accidents audit plan & 0.250 & 0.222 & 0.271 & 0.247 \\
\hline Special medical service & 0.229 & 0.203 & 0.166 & 0.199 \\
\hline Nutrition care plan & 0.118 & 0.142 & 0.120 & 0.128 \\
\hline Health assessment service & 0.093 & 0.151 & 0.138 & 0.128 \\
\hline
\end{tabular}

\subsection{Within the Hardware Planning Category}

According to a veterans health study carried out by Kazis, et al. (1998) indicated that $36 \%$ of the patients had a disability. Duh et al. (2008) also reported that the incidence of injurious falls among American community-dwelling older adults ranged from 9.5 to 15.8 per 1000 person-years. Furthermore, a similar survey conducted by Chu et al. (2008) revealed that the fall rate in the Hong Kong Special Administrative Region of China was $26.4 \%$.

Table 9 shows that 'safety of institution' $(0.377)$ is the major critical successful factor within the hardware planning category, this was followed by 'no-barrier facilities' (0.372), 'local environment' (0.109) and 'comfortable environment' (0.076). Leung et al. (2010) agreed and stated that a high standard of care management service demonstrated a significant preventive effect on falls in the Chinese population. It reduced the risk of falling by $73 \%$. They further indicated that cognitive impairment, unsteady gait, perceived poor health status, dizziness and depression were identified as the significant factors related with falls. Therefore, the safety of an institution will be a major factor to prevent the incidence of injurious falls in the Taiwanese Veterans Home.
The author's survey results also revealed a CR of 0.02 (VAC officer), 0.01 (VH administrator) and 0.02 (academic professor) within the hardware planning category. The Consistency Rate (CR) provides a measure of the logical rationality of the pair-wise comparison, these figures are all less than 0.10 so they are generally considered acceptable.

\subsubsection{Within the Health Care System Category}

Nakatani and Shimanouchi (2004) suggested that it is important to develop a care plan based on the necessary amount of service. Continuous monitoring and evaluation are also essential and these measures lead to satisfactory client outcomes. Leung et al. (2010) further stated that care managers are able to identify the high-risk group of service recipients, allocate resources to develop tailor-made care and eventually monitor the service recipients' progress in a continuous manner.

The author's survey results revealed that 'long-term care planning' $(0.299)$ was considered to be most important critical successful factor within the health care system category. The 'accidents audit plan' (0.247), and 'special medical service' (0.199), ranked second and third most important respectively (see Table 10). These findings concur 
with the survey conducted by Leung et al. (2004) who indicated that the major important reason for moving to a Continuing Care Retirement Community (CCRC) was to seek continuing care. They further stated that the long-term care provided by a CCRC is a paramount motivator for moving there.

Table 11. The overall results of pair-wise comparison from the VAC officer opinion

\begin{tabular}{|c|c|c|c|c|c|}
\hline \multicolumn{2}{|c|}{ The second level } & \multicolumn{2}{|c|}{ The third level } & \multirow{2}{*}{$\begin{array}{l}\text { Combined } \\
\text { weight }\end{array}$} & \multirow{2}{*}{$\begin{array}{l}\text { The order } \\
\text { of priority }\end{array}$} \\
\hline Criteria & Weight & Sub-criteria & Weight & & \\
\hline \multirow{5}{*}{$\begin{array}{l}\text { Executive } \\
\text { strategy }\end{array}$} & \multirow{5}{*}{0.338} & Institution category and size & 0.160 & 0.054 & 8 \\
\hline & & Strategy alliance & 0.104 & 0.035 & 10 \\
\hline & & Bed occupancy rate & 0.085 & 0.029 & 11 \\
\hline & & Community network & 0.086 & 0.029 & 12 \\
\hline & & Quality of professional team & 0.565 & 0.191 & 1 \\
\hline \multirow{5}{*}{$\begin{array}{l}\text { Hardware } \\
\text { planning }\end{array}$} & \multirow{5}{*}{0.155} & Colour planning & 0.065 & 0.010 & 14 \\
\hline & & Comfortable environment & 0.061 & 0.009 & 15 \\
\hline & & Safety of institution & 0.384 & 0.060 & 5 \\
\hline & & Local environment & 0.113 & 0.017 & 13 \\
\hline & & No-barrier facilities & 0.378 & 0.059 & 7 \\
\hline \multirow{5}{*}{$\begin{array}{l}\text { Health care } \\
\text { system }\end{array}$} & \multirow{5}{*}{0.507} & Special medical service & 0.229 & 0.116 & 4 \\
\hline & & Accidents audit plan & 0.250 & 0.127 & 3 \\
\hline & & Long-term care planning & 0.310 & 0.157 & 2 \\
\hline & & Nutrition care plan & 0.118 & 0.060 & 6 \\
\hline & & Health assessment service & 0.093 & 0.047 & 9 \\
\hline
\end{tabular}

Table 12. The overall results of pair-wise comparison from the VH administrator opinion

\begin{tabular}{|c|c|c|c|c|c|}
\hline \multicolumn{2}{|c|}{ The second level } & \multicolumn{2}{|c|}{ The third level } & \multirow{2}{*}{$\begin{array}{l}\text { Combined } \\
\text { weight }\end{array}$} & \multirow{2}{*}{$\begin{array}{l}\text { The order } \\
\text { of priority }\end{array}$} \\
\hline Criteria & Weight & Sub-criteria & Weight & & \\
\hline \multirow{5}{*}{$\begin{array}{l}\text { Executive } \\
\text { strategy }\end{array}$} & \multirow{5}{*}{0.230} & Institution category and size & 0.180 & 0.041 & 9 \\
\hline & & Strategy alliance & 0.103 & 0.024 & 14 \\
\hline & & Bed occupancy rate & 0.143 & 0.033 & 10 \\
\hline & & Community network & 0.115 & 0.027 & 13 \\
\hline & & Quality of professional team & 0.459 & 0.105 & 4 \\
\hline \multirow{5}{*}{$\begin{array}{l}\text { Hardware } \\
\text { planning }\end{array}$} & \multirow{5}{*}{0.288} & Colour planning & 0.073 & 0.021 & 15 \\
\hline & & Comfortable environment & 0.102 & 0.029 & 12 \\
\hline & & Safety of institution & 0.377 & 0.109 & 2 \\
\hline & & Local environment & 0.108 & 0.031 & 11 \\
\hline & & No-barrier facilities & 0.341 & 0.098 & 5 \\
\hline \multirow{5}{*}{$\begin{array}{l}\text { Health care } \\
\text { system }\end{array}$} & \multirow{5}{*}{0.482} & Special medical service & 0.203 & 0.098 & 6 \\
\hline & & Accidents audit plan & 0.222 & 0.107 & 3 \\
\hline & & Long-term care planning & 0.282 & 0.136 & 1 \\
\hline & & Nutrition care plan & 0.142 & 0.068 & 8 \\
\hline & & Health assessment service & 0.151 & 0.073 & 7 \\
\hline
\end{tabular}

\subsection{The Overall Results Of Hierarchy Model}

Turnover of nursing aides, licensed practical nurses and registered nurses in nursing homes has been a subject of research for the past decades. This interest has primarily been the result of consistently high rates of turnover identified for these caregivers in many facilities. (Castle \& Engberg, 2005). Castle \& Engberg (2005) further reported that understanding turnover in nursing homes is important. This is because turnover can influence facility operating costs, lower care-giver job satisfaction and have negative health outcomes for residents. 
Castle (2008) agreed and stated that probably the most important concern about staff turnover is its potential association with quality of care. In general, high staff turnover is associated with poor quality. The critical successful factors of business management in the Taiwanese Veterans Home have been identified in the author's survey. The results are illustrated in Table $11,12,13,14$ and indicate that the top six critical successful factors are:

- Service quality of the professional team;

- Long-term care planning;

- Accidents audit plan;

- Safety of the institution;

- Special medical service;

- No-barrier facilities.

Table 13. The overall results of pair-wise comparison from the academic professor opinion

\begin{tabular}{|c|c|c|c|c|c|}
\hline \multicolumn{2}{|c|}{ The second level } & \multicolumn{2}{|c|}{ The third level } & \multirow{2}{*}{$\begin{array}{l}\text { Combined } \\
\text { weight }\end{array}$} & \multirow{2}{*}{$\begin{array}{c}\text { The order of } \\
\text { priority }\end{array}$} \\
\hline Criteria & Weight & Sub-criteria & Weight & & \\
\hline \multirow{5}{*}{$\begin{array}{l}\text { Executive } \\
\text { strategy }\end{array}$} & \multirow{5}{*}{0.327} & Institution category and size & 0.180 & 0.059 & 7 \\
\hline & & Strategy alliance & 0.098 & 0.032 & 10 \\
\hline & & Bed occupancy rate & 0.065 & 0.021 & 13 \\
\hline & & Community network & 0.092 & 0.030 & 12 \\
\hline & & Quality of professional team & 0.566 & 0.185 & 1 \\
\hline \multirow{5}{*}{$\begin{array}{c}\text { Hardware } \\
\text { planning }\end{array}$} & \multirow{5}{*}{0.301} & Colour planning & 0.060 & 0.018 & 15 \\
\hline & & Comfortable environment & 0.066 & 0.020 & 14 \\
\hline & & Safety of institution & 0.370 & 0.111 & 4 \\
\hline & & Local environment & 0.106 & 0.032 & 11 \\
\hline & & No-barrier facilities & 0.398 & 0.120 & 2 \\
\hline \multirow{5}{*}{$\begin{array}{l}\text { Health care } \\
\text { system }\end{array}$} & \multirow{5}{*}{0.373} & Special medical service & 0.166 & 0.062 & 6 \\
\hline & & Accidents audit plan & 0.271 & 0.101 & 5 \\
\hline & & Long-term care planning & 0.305 & 0.114 & 3 \\
\hline & & Nutrition care plan & 0.120 & 0.045 & 9 \\
\hline & & Health assessment service & 0.138 & 0.051 & 8 \\
\hline
\end{tabular}

Table 14. The overall results of hierarchy model

\begin{tabular}{|c|c|c|c|c|c|}
\hline Sub-criteria & VAC officer & VH administrator & $\begin{array}{c}\text { Academic } \\
\text { professor }\end{array}$ & $\begin{array}{c}\text { The } \\
\text { overall }\end{array}$ & $\begin{array}{c}\text { The order of } \\
\text { priority }\end{array}$ \\
\hline Institution category and size & 0.054 & 0.041 & 0.059 & 0.051 & 9 \\
\hline Strategy alliance & 0.035 & 0.024 & 0.032 & 0.020 & 13 \\
\hline Bed occupancy rate & 0.029 & 0.033 & 0.021 & 0.028 & 11 \\
\hline Community network & 0.029 & 0.027 & 0.030 & 0.029 & 10 \\
\hline Quality of professional team & 0.191 & 0.105 & 0.185 & 0.160 & 1 \\
\hline Colour planning & 0.010 & 0.021 & 0.018 & 0.016 & 15 \\
\hline Comfortable environment & 0.009 & 0.029 & 0.020 & 0.019 & 14 \\
\hline Safety of institution & 0.060 & 0.109 & 0.111 & 0.093 & 4 \\
\hline Local environment & 0.017 & 0.031 & 0.032 & 0.027 & 12 \\
\hline No-barrier facilities & 0.059 & 0.098 & 0.120 & 0.092 & 6 \\
\hline Special medical service & 0.116 & 0.098 & 0.062 & 0.092 & 5 \\
\hline Accidents audit plan & 0.127 & 0.107 & 0.101 & 0.112 & 3 \\
\hline Long-term care planning & 0.157 & 0.136 & 0.114 & 0.136 & 2 \\
\hline Nutrition care plan & 0.060 & 0.068 & 0.045 & 0.058 & 7 \\
\hline Health assessment service & 0.047 & 0.073 & 0.051 & 0.057 & 8 \\
\hline
\end{tabular}




\section{Discussion}

According to VAC, Taiwan (2011) projections, the number of veterans age 80 and over will increase by $20 \%$ between 2011 and 2021 . The growth in very elderly veterans is resulting in increased demands for long-term care, including special needs such as hospice care and care for Alzheimer's and other dementia conditions. One unique characteristic of older Taiwanese veterans that affect service needs is the high proportion of males $-97 \%$ of veterans over the age of 65 are males, compared to $50 \%$ for the country population as a whole - and the presence of wartime disabilities, both physical and mental. There are approximately 10,000 veterans aged 65 and over in Taiwan are currently receiving war-related disability compensation or pensions from the central government (VAC Taiwan, 2011).

In order to take care of the veterans who have contributed to the country and spent half of their life defending the country, the VAC is assigned with responsibilities to assist in medical care, home care and other general services. These services were designed to improve their quality of later life. To the end of April 2011, Taiwanese veterans homes provide 6,862 beds at the government's expense and 2,769 beds at a self-expense domiciliary. Currently, 6,577 veterans (government's expense) and 2,107 veterans (self-expense) are living in veterans homes, with bed occupancy rates of $96 \%$ and 76\% (Veterans Affairs Commission, 2011).

Although Taiwanese veterans homes are public funded health care services, Holmes (1996) indicated that a proxy measure of financial performance is the occupancy rate of the facility. Kaplan and Norton (2001) agreed and stated that both profit and non-profit organisations need to focus on profitability and customer satisfaction in order to maintain sustainable business operations. Therefore, it is important to increase the occupancy rate of the facility for Taiwanese veterans homes on future developments.

The critical successful factors of business management in the Taiwanese Veterans Home have been identified in the author's survey. The top six critical successful factors are: (1) service quality of the professional team; (2) long-term care planning; (3) accidents audit plan; (4) safety of the institution; (5) special medical service; (6) no-barrier facilities. The findings in the author's survey are similar to the research conducted by Leung et al. (2004) who identified the most important general considerations in selecting a CCRC were respectively; continuing care $(71.4 \%)$, on-site medical services $(60.4 \%)$, a desire to remain independent $(36.3 \%)$, the reputation of the facility $(35.2 \%)$, the size, design, or choice of the living units $(31.9 \%)$ and the facility's reputation for being well-managed $(30.8 \%)$. However the order of importance of the various critical successful factors is slightly changed.

The author's survey results also concur with the survey carried out by Chen et al. (2008) who revealed that $8.2 \%$ of Taiwanese veterans home residents reported a history of falls in the proceeding 180 days. They further indicated that 'accidents audit plan' and 'no-barrier facilities' are two preventive strategies for falls in the Taiwanese Veterans Home. In addition, the findings in the author's survey are confirmed by $\mathrm{Ku}$ et al. (2006) who indicated that prevalence of depressive tendency is $35.5 \%$ of veterans home residents in eastern Taiwan. They further identified that depressive status is significantly predicted by poor functional status, dissatisfaction with living situation, poor perceived health status and lower education level. Additionally, they concluded that Taiwanese veterans home need to be considered when assessing the health of older veterans and developing future interventions for residents, such as 'long-term care planning' and 'special medical service' etc.

In general, critical success factors are common to most businesses that assist management in measuring whether they are on track toward reaching profit and market share goals. Phillips (2002) agreed and stated that some nursing homes are better than others, because some nursing homes are more effective organisations than other nursing homes. Castle (2008) also believed that the organisational context can help differentiate between more and less effective organisations with respect to turnover and vacancy rates. Finally, Yusuf (1995) identified several critical factors for success in small and medium business as follows: (1) good management (4.36); (2) access to finances and level of initial investment (3.70); (3) personal qualities (3.67); (4) satisfactory government support (3.65); (5) level of education and training. Although the order of importance of critical successful factors is changed, Yusuf (1995) survey results are similar to the author's survey findings.

\section{Limitations of the Research}

Several limitations and constraints have influenced the response obtained in this research:

- Unfamiliarity of AHP applications: AHP is a relatively new tool, particularly in the Taiwanese Veterans Home and therefore some respondents were unfamiliar with the AHP applications available or even the esoteric terminology used.

- Constraints of conducting structured interviews: Although a substantial empirical study was conducted using three questionnaire surveys, the expense and time-consuming nature of conducting structured interviews limited the number that were able to be carried out.

- Analysis constraints: Some difficulty was experienced in analysing some of the survey respondent's comments, due to their subjectivity.

\section{Conclusion}

Population aging is a global phenomenon that affects both developing and developed countries, and Taiwan is no exception. Taiwan was estimated to become the fastest aging 
country in the world, and the percentage of older population in Taiwan will be doubled from 2010 to 2025 (Chiang et al., 2012). The escalation of older population may cause various challenges to health care systems which include Taiwanese veterans care system. Among this older population, one in six older Taiwanese is a veteran (VAC, 2011) and they have unique characteristics. The majority of Taiwanese veterans are single. Their languages, habits and value systems were different from those of local people, making it difficult for them to form new social networks and to get a job $(\mathrm{Ku}$ et al., 2006).

Currently, there are a lot of challenges facing Taiwanese veterans homes on future developments. For example, the growth in very elderly veterans is resulting in increased demands for long-term care, including special needs such as hospice care and care for Alzheimer's and other dementia conditions. The prevalence of dementia was $5.9 \%-9.4 \%$ in community-dwelling elderly and $57.2 \%$ among residents living in long-term care facilities. Cognitive dysfunction also shares many common risk factors with falls, such as visual impairment, muscle strength and balance (Chen et al., 2008). Falls and related injuries are therefore the major issues of care in the Taiwanese veterans homes.

A study of veterans home in Taiwan showed that $8.2 \%$ of residents reported a history of falls in the preceding 180 days (Chen et al., 2008). About one-third of falls in care homes resulted in various physical injuries, of which $3 \%-5 \%$ were fractures (Rubenstein et al., 1996). In addition to physical injuries, falls have tremendous impact on the elderly in terms of loss of function, anxiety, depression and increased economic burden. The no-barrier environment and facilities is therefore an important preventive strategy for falls in the Taiwanese Veterans Home. This concept is confirmed by the author's survey results, there are $52 \mathrm{VAC}$ officers, veterans home administrators and academic professors identified that 'no-barrier facilities', 'accidents audit plan' and safety of the institution' are three critical successful factors of business management in the Taiwanese Veterans Home.

The author's survey results also revealed that another three critical successful factors of business management in the Taiwanese Veterans Home are 'service quality of the professional team', 'long-term care planning' and 'special medical service'. Ku et al. (2006) agreed and stated that the prevalence of depression in the elderly around the world is high. According to their survey results reported that $35.5 \%$ of veterans home residents have revealed depressive symptoms in eastern Taiwan. Preventing suffering from depression and detecting depressive symptoms earlier for the elderly has become an important issue for health care systems worldwide.

\section{Acknowledgements}

The authors would like to acknowledge the contribution of the VAC officers, Taiwanese Veterans Home administrators and academic professors who participated in this survey.

\section{REFERENCES}

[1] Abbott, K. H., Stoller, E. P. \& Rose, J. H. (2007), 'The Structure and Function of Frail Male Veterans' Informal Networks', Journal of Aging and Health, Vol. 19 No. 5, October 2007, pp. 757-777

[2] Castle, N. G. (2001), 'Administrator Turnover and Quality of Care in Nursing Homes', The Gerontologist, 41(6), pp. $1-11$

[3] Castle, N. G. (2008), 'State Differences and Facility Differences in Nursing Home Staff Turnover', The Journal of Applied Gerontology, Vol. 27 No. 5, November 2008, pp. 609-630

[4] Castle, N. G. \& Banaszak-Holl, J. (2003), 'The Effect of Administrative Resources on Care in Nursing Homes', The Journal of Applied Gerontology, Vol. 22 No. 3, September 2003, pp. 405-424

[5] Castle, N. G., \& Engberg, J. (2005), 'Staff turnover and quality of care in nursing homes', Medical Care, 43(6), pp. 616-626

[6] Castle, N. G. \& Shugarman, L. R. (2005), 'The Effects of Top Management Professional Development on Administrator Turnover', The Journal of Applied Gerontology, Vol. 24 No. 5, November 2005, pp. 404-418

[7] Chen, S. H., Yang, C. C. \& Shiau, J. Y. (2006), 'The Application of Balanced Scorecard in the Performance Evaluation of Higher Education', The TQM Management, 18(2), pp. 190-205

[8] Chen, Y. M., Hwang, S. J., Chen, L. K., Chen, D. Y. \& Lan, C. F. (2008), 'Risk Factors for Falls Among Elderly Men in a Veterans Home'. Journal of Chinese Medical Association, 71(4), pp. 180-185

[9] Chiang, C. H., Chou, M. Y. \& Chou, S. L. et al. (2012), 'Risk Factors for Frequent Emergency Department Visits of Veterans Home Residents in Northern Taiwan'. Journal of Clinical Gerontology \& Geriatrics, 3 (2012), pp. 118-121

[10] Childs, N. (2000), 'Nursing Facility Bankruptcies Top 10 Percent in 21 States', Provider, p. 1

[11] Christensen, C. \& Beaver, S. (1996), 'Correlation between Administrator Turnover and Survey Results', Journal of Long-Term Care Administration, 24(2), pp. 4-7

[12] Chu, L. W., Chiu, A. Y. Y., \& Chi, I. (2008), 'Falls and subsequent health service utilization in community-dwelling Chinese older adults', Archives of Gerontology and Geriatrics, 46(2), pp. 125-135

[13] Coyle, G. (2004), 'The Analytic Hierarchy Process', Pearson Education Limited, USA

[14] Critical conditions (2000), 'American health care is the best in the world-If you can get it', The Economist, 356, pp. $18-19$

[15] Curry, N. (2012), 'Low Cost and High Quality Integrated Care: What Can We Learn from Japan?'. Social Care Network, Published: 11 June 2012. available online at: 
http://www.theguardian.com/social-care-network/2012/jun/1 1/integrated-care-learn-from-japan

[16] Dalton, L., Frew, T., Dohle, J. \& Madden, R. (2008), 'A Frontier of Opportunity: Critical Success Factors of Employee Volunteering Programs for the Small-to-Medium Not-for-Profit Sector', Research Report, The Centre for Volunteering, Austrilia, ISBN 978-0-9775429-0-1

[17] Dey, P. K. (2002), 'Project Risk Management: A Combined Analytic Hierarchy Process and Decision Tree Approach', Cost Engineering, Vol. 44/No.3 March 2002.

[18] Duh, M. S., Mody, S. H., Lefebvre, P., Woodman, R. C., Buteau, S., \& Piech, C. T. (2008), 'Anaemia and the risk of injurious falls in a community-dwelling elderly population', Drugs \& Aging, 25, pp. 325-334

[19] Fletcher, H. D. \& Smith, D. B. (2004), 'Managing for Value: Developing a Performance Measurement System Integrating Economic Value Added and the Balanced Scorecard in Strategic Planning,, Journal of Business Strategy, 24(1) pp. $1-18$

[20] Hepler, G. and Mazur, G. (2007), 'The Analytic Hierarchy Process: Methodologies and Application with Customers and Management at Blue Cross Blue Shield of Florida', The Proceeding of 19th Symposium on QFD (2007), pp. 137-149.

[21] General Accounting Office (1999a), 'Nursing homes: Additional steps needed to strengthen enforcement of federal quality standards', (GAO/HEHS-99-46), Washington DC, USA

[22] General Accounting Office (1999b), 'Nursing homes: Complaint investigation process often inadequate to protect residents', (GAO/HEHS-99-80), Washington DC, USA

[23] General Accounting Office (1999c), 'Nursing homes: Proposal to enhance oversight of poorly performing homes has merit', (GAO/HEHS-99-157), Washington DC, USA

[24] Harrington, C., Zimmerman, D., Karon, S. L., Robinson, J. \& Beutel, P. (2000), 'Nursing Home Staffing and Its Relationship to Deficiencies', Journal of Gerontology: Social Sciences, 55B (5), pp. 278-287

[25] Holmes, J. S. (1996), 'The effects of ownership and ownership changes on nursing home industry costs', Health Services Research, 31(3), pp. 327-346

[26] Institute of Medicine (1986), 'Improving the quality of care in nursing homes', Washington, DC: National Academy Press, USA

[27] Kamal M. Al-Subhi Al-Harbi (2001), 'Application of the AHP in Project Management', International Journal of Project Management, 19 (2001) pp.19-27 Elsevier Science Ltd

[28] Kaplan, R. \& Norton, D. (2001), 'Transforming the Balanced Scorecard from Performance Measurement to Strategic Management: Part I', Accounting Horizons Vol. 15 No. 1 (March 2001), pp. 87 - 104.

[29] Kaplan, R. S. \& Norton, D. P. (2004), 'Strategy Maps: Converting Intangible Assets into Tangible Outcomes', Harvard Business School Press, Boston: USA

[30] Kazis, L. E., Miller, D. R., Clark, J., Skinner, K., Lee, A.,
Rogers,W. (1998), 'Health-related quality of life in patients served by the department of veteran affairs: Results from the veterans health study', Archives of Internal Medicine, Vol.158, March 1998, pp. 626-32.

[31] Kendrick, J. D. and Saaty, D. (2007), 'Using AHP for Project Selection', Six Sigma Forum Magazine, August 2007, pp. 22-29

[32] Ku, Y. C., Liu, W. C. \& Tsai, Y. F. (2006), 'Prevalence and Risk Factors for Depressive Symptoms Among Veterans Home Elders in Eastern Taiwan'. International Journal of Geriatric Psychiatry, 21, pp. 1181-1186

[33] Kumar, S., Parashar, N. \& Haleem, A. (2009), 'Analytical Hierarchy Process Applied to Vendor Selection Problem: Small Scale, Medium Scale and Large Scale Industries', Business Intelligence Journal, August, 2009 Vol.2 No.2 pp.355-362

[34] Lawrence S, Sharma U (2002), 'Commodification of education and academic labour-Using the Balanced Scorecard in a university setting', Crit. Vis. Accounting, 13, pp. 661-677

[35] Leung, A. Y. M., Lou, V. W.Q., Chan, K. S., Yung, A. \& Chi, I. (2010), 'Care Management Service and Falls Prevention: A Case Control Study in a Chinese Population', Journal of Aging and Health, 22(3), pp. 348-361

[36] Leung, A. C. T., Liu, C. P., Chow, N. W. S. \& Chi, I. (2004), 'Reasons for Relocation to a Continuing Care Retirement Community', The Journal of Applied Gerontology, Vol. 21 No. 2, June 2002, pp. 236-256

[37] Marzialli, E., Shulman, K. \& Damianakis, T. (2006), 'Persistent Family Concerns in Long-Term Care Settings: Meaning and Management', Journal of the American Medical Directors Association, 7(3), pp. 154-162

[38] MindTools (2013), 'Critical Success Factors', available online at:

https://depts.washington.edu/oei/resources/toolsTemplates/cr it_success_factors.pdf

[39] Mollenhauer, L. (2006), 'A framework for success for not-for-profit federations', Project report of Schizophrenia Society of Canada, Funded by the Public Health Agency of Canada, September, 2006

[40] Mueller, C., Arling, G., Kane, R., Bershadsky, J., Holland, D. \& Joy, A. (2006), 'Nursing Home Staffing Standards: Their Relationship to Nurse Staffing Levels', The Gerontologist, 46(1), pp. 74-80

[41] Naoum, S. G. (1998), "Dissertation Research and Writing for Construction Students", Butterworth-Heinemann, Oxford UK, ISBN 0-7506-2988-6

[42] Nakatani, H. \& Shimanouchi, S. (2004), 'Factors in care Management Affecting Client Outcomes in Home Care. Nursing and Health Sciences, 6, pp. 239-246

[43] Parsons, S. K., Simmons, W. P., Penn, K. \& Furlough, M. (2003), 'Determinants of Satisfaction and Turnover among Nursing Assistants - The results of a statewide survey', Journal of Gerontological Nursing, 29(3), pp. 51-58

[44] Phillips, C. D. (2002), 'Yali's question and the study of nursing homes as organizations', The Gerontologist, 42(2), pp. $154-156$ 
[45] Port, C. L., Gruber-Baldini, A. L., Burton, L., Baumgarten, M., Hebel, J. R. \& Zimmerman, S. I. (2001), 'Resident Contact with Family and Friends Following Nursing Home Admission', Gerontologist, 41(5), pp. 589-596

[46] Predrag, P. (2011), 'BSC Modeling in Non-Profit Organisation', The proceeding of 5th International Quality Conference, 20th of May 2011, Srpske

[47] Rowles, G. D. \& High, D. M. (2003), 'Family Involvement in Nursing Home Facilities: A Decision-Making Perspective', In Stafford, P. B. (Ed.), 'Gray Areas: Ethnographic Encounters with Nursing Home Culture' (pp. 173-301). Santa Fe: School of American Research Press.

[48] Rubenstein, L. Z., Josephson, K.R. \& Osterweil, L.D. (1996), 'Falls and Fall Prevention in the Nursing Home. Clin Geriatr Med, 12, pp. 881-902.

[49] Rubin, A. \& Shuttlesworth, G. E. (1986), 'Job Turnover Among Nursing Home Administrators: An Exploratory Study', Journal of Long-Term Care Administration, 14(2), pp. 25-29

[50] Saaty, T.L. (1990), 'How to Make a Decision: The Analytic Hierarchy Process', European Journal Operation Research, Vol. 48, pp. 9-26

[51] Saaty, T. L. (2008), 'Decision making with the Analytic Hierarchy Process', International Journal of Service Sciences, Vol. 1 No. 1, Inderscience Enterprises Ltd.

[52] Singh, D. A., Amidon, R. L., Shi, L. \& Samuels, M. E. (1996), 'Predictors of quality of care in nursing facilities', Journal of Long-Term Care Administration, 24(3), pp. 22-26

[53] Singh, D. A. \& Schwab, R. C. (1998), 'Retention of Administrators in Nursing Homes: What Can Management do?' The Gerontologist, 38, pp. 362-369

[54] Soderstrom, I. M., Benzein, E. \& Saveman, B. I. (2003), 'Nurses' experiences of interactions with family members in intensive care units', Scandinavian Journal of Caring
Sciences, 17(2), pp. 185-192

[55] Udo, G. G. (2000), 'Using Analytic Hierarchy Process to Analyse the Information Technology Outsourcing Decision', Industrial Management \& Data Systems, 100/9 (2000), pp. 421-429

[56] Utley-Smith, Q., Colón-Emeric, C. S., Lekan-Rutledge, D., Ammarell, N., Bailey, D., Corazzini, K., Piven, M. L. \& Anderson, R. A. (2010), 'Staff Perceptions of Staff-Family Interactions in Nursing Homes', Journal of Aging Studies, 23(2009), pp. 168-177

[57] Veterans Affirs Commision (2011), 'Organisational Structure', 31st of May 2011, available from http://www.vac.gov.tw/en/content/index01.asp?pno=33\&sno $=137$,

[58] Washington State Department of Veterans Affairs (2006), '2007-2011 Strategic Plan', USA, Retrieved September 9, 2011 from

http://www.dva.wa.gov/PDF\%20files/2007\%20-\%202011\% 20Strategic\%20Plan.pdf

[59] Wilder, S. C. (2005), 'North Carolina State Long-term Care Ombudsman Program' 2005 Annual Report, p. 29, Retrieved August 8, 2011 fromhttp://www.ncdhhs.gov/aging/ombud/A nnualOmbudsmanReport2005.pdf

[60] Wilson, C., Hagarty, D. \& Gauthier, J. (2003), 'Result using the balanced scorecard in the public sector', Journal of Corporate Real Estate, Dec., 6(1) pp. 53-63

[61] Wong, O. (2013), 'Cost of Caring for Hong Kong's Elderly to Rise by Billions'. South China Morning Post. Published: 29 August 2013.

[62] Yusuf, A. (1995), 'Critical Successful Factors for Small Business'. Journal of Small Business Management, 33(2), pp. $68-73$ 